\title{
FROG SKIN ACTIVE PEPTIDES (FSAP) AS A HIGHY EFFECTIVE ANTIMICROBIAL AGENTS
}

\author{
Gilev M. ${ }^{1}$, G. Bontchev ${ }^{2}$ \\ ${ }^{1}$ Medical Centre "St. Anna" - Varna, Dept. of Orthopedics and Traumatology, \\ ${ }^{2}$ Medical University "Prof. P. Stoyanov" - Varna, Dept. of Pharmacology, \\ Chemistry, Biochemistry and Biology
}

Reviewed by: Assoc. Prof. N. Negrev

\begin{abstract}
During last ten to fifteen years a considerable scientific attention has been paid to biologically active substances as known as frog skin active peptides (FSAP). These substances are naturally produced by many Amphibian organisms and could be found within skin secretion of most frog families, especially Ranidae. Biomolecules of that class possess extremely valuable properties: show high antimicrobial and antifungal activity - especially effective against multiresistant bacterial infections; act as protease inhibitors and components of an innate immune system; demonstrate relatively weak hemolytic activity. Such a combination makes frog skin active peptides a potential candidates for drug development with possible application in therapy, traumatology, surgery, etc. In present paper an origin, classification, function as well as methods for determination of FSAP are summarized. It is underlined that Bulgarian region is definitely suitable for extensive FSAP investigations due to the naturally abundance of genus Rana species.
\end{abstract}

Key words: frog skin active peptides (FSAP), antimicrobial peptides, multiresistant bacterial infections, drug development

\section{What are FSAP?}

Frog skin active peptides (FSAP) are naturally produced polypeptides of 20-30 AA length and 2000-3000 Da molecular weight in average; there are extreme exceptions though. It was shown many times that FSAP are important skin secretion components of organisms belonging to class Amphibia, subclass Lissamphibia (frogs, toads, salamanders, newts, etc.).

Due to the increasing interest nowadays, the number of isolated and studied FSAP substances constantly grows (now exceeds 200); there are even some correspondent nomenclature problems raised (6).

The systematical research on FSAP has begun in the early 1990s. It appears that frog skin active peptides could be categorized in groups (peptide lines) and in peptide families within these lines. On the basis of limited structural similarity, at least 11 well-established peptide lines have been identified so far (6). In Table 1 a brief information concerning known FSAP lines is given; more detailed data on major representatives could be found in Table 2 .

\footnotetext{
Address for correspondence:

G. Bontchev, Dept. of Pharmacology, Chemistry, Biochemistry and Biology, Faculty of Dental Medicine, Medical University "Prof. P. Stoyanov" - Varna, 55 Marin Drinov Str., 9002-Varna, Bulgaria e-mail: bontchev@mu-varna.bg
}

Why world scientists are interested in FSAP?

Table 1. FSAP lines identified so far (data retrieved from $(39,40))$.

\begin{tabular}{||l|c|c|c|c||}
\hline \hline No & $\begin{array}{c}\text { FSAP line } \\
\text { name }\end{array}$ & $\begin{array}{c}\text { Known } \\
\text { members }\end{array}$ & $\begin{array}{c}\text { First } \\
\text { reported }\end{array}$ & in Ref. \\
\hline $\mathbf{1}$ & Brevinins & 62 & 1992 & $(21)$ \\
\hline $\mathbf{2}$ & Esculentins & 12 & 1993 & $(29)$ \\
\hline $\mathbf{3}$ & Ranalexins & 3 & 1994 & $(5)$ \\
\hline $\mathbf{4}$ & Temporins & 40 & 1995 & $(31)$ \\
\hline $\mathbf{5}$ & Rugosins & 3 & 1995 & $(32)$ \\
\hline $\mathbf{6}$ & Ranatuerins & 24 & 1998 & $(12)$ \\
\hline $\mathbf{7}$ & Palustrins & 11 & 2000 & $(1)$ \\
\hline $\mathbf{8}$ & Nigrocins & 5 & 2001 & $(24)$ \\
\hline $\mathbf{9}$ & Japonicins & 3 & 2002 & $(13)$ \\
\hline $\mathbf{1 0}$ & Ranacyclins & 2 & 2003 & $(16)$ \\
\hline $\mathbf{1 1}$ & Pipinins & 1 & 2005 & $(20)$ \\
\hline \hline
\end{tabular}


Immediately after the isolation of first frog skin active peptides, an attention has been drawn upon their significant biological activity. In general, antimicrobial function appears to be the most important FSAP' feature. Combining the antimicrobial function with some other FSAP' advantages, it becomes clear why these peptides are often spoken of as "natural antibiotics" as well as propositions for drug development on their basis are periodically being discussed. The FSAP and their modifications may become ex-
Candida albicans, Candida tropicalis, Candida krusei and Candida parapsilosis. The peptide is highly hemolytic for human erythrocytes, but derivatives in which the cysteine residues are replaced by serine to produce an acyclic analog reduces hemolytic activity while retaining high antimicrobial potency. Brevinin-ALb has been shown to induce mast cell degranulation and histamine release, and is cytotoxic for solid tumor cell line HepG2 (14).

Esculentins are very active against Staphylococcus aureus,

Table 2. Some typical FSAP details.

\begin{tabular}{|c|c|c|c|}
\hline Peptide name & $\begin{array}{c}\text { AA } \\
\text { Length }\end{array}$ & $\begin{array}{c}\text { Molecular } \\
\text { weight }\end{array}$ & AA Sequence \\
\hline Brevinin-1 & 24 & 2531 & $\begin{array}{c}\text { FLPVLAGIAA }^{10} \mathrm{KVVPALFCKI}^{20} \mathrm{TKKC}^{-} \\
\text {(disulfide bridge: } 18-24 \text { ) }\end{array}$ \\
\hline Brevinin-2 & 33 & 3254 & $\begin{array}{c}\text { GLLDSLKGFA }^{10} \text { ATAGKGVLQS }^{20} \text { LLSTASCKLA }^{30} \mathrm{KTC} \\
\text { (disulfide bridge: } 27-33 \text { ) }\end{array}$ \\
\hline || Esculentin-1 & 46 & 4888 & $\begin{array}{c}\text { GIFSKLGRKK }^{10} \text { IKNLLISGLK }^{20} \text { NVGKEVGMDV }^{30} \\
\text { VRTGIDIAGC } \\
\text { (disulfide bridge: } 40 \text {-46) }\end{array}$ \\
\hline Japonicin-1 & 14 & 1650 & $\begin{array}{l}\text { FFPIGVFCKI }{ }^{10} \mathrm{FKTC} \\
\text { (disulfide bridge: } 8-14 \text { ) }\end{array}$ \\
\hline Japonicin-2 & 21 & 2358 & $\begin{array}{l}\text { FGLPMLSILP }^{10} \text { KALCILLKRK }^{20} \mathrm{C} \\
\text { (disulfide bridge: } 14-21 \text { ) }\end{array}$ \\
\hline Nigrocin-2 & 21 & 2031 & $\begin{array}{l}\text { GLLSKVLGVG }^{10} \mathrm{KKVLCGVSGL}^{20} \mathrm{C} \\
\text { (disulfide bridge: } 15-21 \text { ) }\end{array}$ \\
\hline Ranacyclin-E & 17 & 1906 & $\begin{array}{l}\text { SAPRGCWTKS }{ }^{10} \text { YPPKPCK } \\
\text { (disulfide bridge: 6-16) }\end{array}$ \\
\hline Ranalexin & 66 & 7615 & $\begin{array}{l}\text { MFTLKKSLLL }^{10} \text { LFFLGTINLS }^{20} \text { LCEEERNAEE }^{30} \\
\text { ERRDNPDERD }^{40} \text { VEVEKRFLGG }^{50} \text { LIKIVPAMIC }^{60} \text { AVTKKC } \\
\text { (disulfide bridge: } 60-66 \text { ) }\end{array}$ \\
\hline Ranatuerin-1 & 25 & 2651 & $\begin{array}{c}\text { SMLSVLKNLG }{ }^{10} \mathrm{KVGLGFVACK}^{20} \mathrm{INKQC} \\
\text { (disulfide bridge: 19-25) }\end{array}$ \\
\hline Temporin-A & 13 & 1398 & FLPLIGRVLS ${ }^{10} \mathrm{GIL}$ \\
\hline Pelophylaxin-2 & 74 & 8070 & 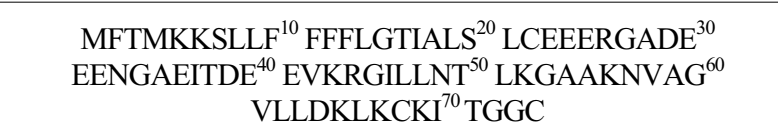 \\
\hline
\end{tabular}

tremely valuable due to high efficiency against multiresistant bacterial infections (18).

Brevinins are known to be active against a wide range of Gram-positive and Gram-negative bacteria and against strains of pathogenic fungi. Brevinin-1 is active against Staphylococcus aureus and Escherichia coli; inactivates infectious Herpes simplex viruses HSV-1 and HSV-2 (35) as well as stimulates insulin release from BRIN-BD11 cells (19). It has been reported (23) that Brevinin-1BYa shows growth inhibitory activity against a range of reference strains of Gram-positive and Gram-negative bacteria, against clinical isolates of methicillin-resistant Staphylococcus aureus (MRSA), and against reference strains and clinical isolates of the opportunistic yeast pathogens and have a much lower hemolytic activity than Brevinin line members. It has been stated that Esculentin-1 also inhibits the growth of Pseudomonas aeruginosa, Candida albicans, and Saccharomyces cerevisiae (30). Chemically synthesized peptide segments corresponding to Esculentin-1 (amino acids 1-15 and 9-27) show antimicrobial activity against Escherichia coli, Mos blue, E. coli 2, Bacillus brevis, B. megaterium, Pseudomonas HTL, and Vibrio mimicus (26). Transgenic tobacco plants expressing Esculentin-1 with the substitution Met-28Leu has been created; these plants have been reported to show enhanced resistance against bacterial or fungal phytopathogens (25). 
Ranalexins have been shown to be most active against Gram-positive bacteria (8), but also against Candida spp. and Cryptosporidium parvum (9), methicillin-resistant Staphylococcus aureus and Staphylococcus epidermidis (10). There are evidences that Ranalexin can prevent bacterial growth, endotoxemia, and mortality in rats with septic shock and also reduces plasma levels of TNF-alpha (7).

Table 3. Natural occurrence of order Anura (Frogs) species in Bulgarian habitat.

\begin{tabular}{|c|c|c|c|}
\hline & Family (5) & Genus (5 & Species (12) \\
\hline \multirow{12}{*}{\begin{tabular}{|l} 
Order \\
Anura \\
(Frogs)
\end{tabular}} & \multirow{2}{*}{ Bombinatoridae } & \multirow{2}{*}{ Bombina } & $\begin{array}{l}\text { Bombina bombina } \\
\text { (European } \\
\text { Fire-bellied Toad) }\end{array}$ \\
\hline & & & $\begin{array}{l}\text { Bombina variegate } \\
\text { (Yellow-bellied toad) }\end{array}$ \\
\hline & \multirow[b]{2}{*}{ Bufonidae } & \multirow[b]{2}{*}{ Bufo } & $\begin{array}{l}\text { Bufo bufo } \\
\text { (Common Toad) }\end{array}$ \\
\hline & & & $\begin{array}{l}\text { Bufo viridis } \\
\text { (European Green } \\
\text { Toad) }\end{array}$ \\
\hline & Hylidae & Hyla & $\begin{array}{l}\text { Hyla arborea } \\
\text { (European tree frog) }\end{array}$ \\
\hline & \multirow{2}{*}{ Pelobatidae } & \multirow{2}{*}{ Pelobates } & $\begin{array}{l}\text { Pelobates fuscus } \\
\text { (Common } \\
\text { Spadefoot) }\end{array}$ \\
\hline & & & $\begin{array}{l}\text { Pelobates syriacus } \\
\text { (Eastern Spadefoot } \\
\text { Toad) }\end{array}$ \\
\hline & \multirow{5}{*}{ Ranidae } & \multirow{5}{*}{ Rana } & $\begin{array}{l}\text { Rana dalmatina } \\
\text { (Agile Frog) }\end{array}$ \\
\hline & & & $\begin{array}{l}\text { Rana kl. Esculenta } \\
\text { (Edible Frog) }\end{array}$ \\
\hline & & & $\begin{array}{l}\text { Rana graeca } \\
\text { (Greek Frog) }\end{array}$ \\
\hline & & & $\begin{array}{l}\text { Rana ridibunda } \\
\text { (Marsh Frog) }\end{array}$ \\
\hline & & & $\begin{array}{l}\text { Rana temporaria } \\
\text { (Common Frog) }\end{array}$ \\
\hline
\end{tabular}

Temporins - both natural and synthetic - have antibacterial activity directed mainly against Gram-positive bacteria. Temporin-A and some synthetic analogs have been shown to possess variable antibiotic activities against a broad spectrum of micro-organisms, including clinically important methicillin-sensitive and -resistant Staphylococcus aureus as well as vancomycin-resistant Enterococcus faecium strains (33); allow the leakage of large-size molecules from the bacterial cells (15); are active against the chytrid fungus (Batrachochytrium dendrobatidis) associated with global amphibian declines (28); induce the migration of human monocytes, neutrophils and macrophages, and stimulates $\mathrm{Ca}^{2+}$ flux in monocytes (3); display anti-Leishmania activ- ity at micromolar concentrations, with no cytolytic activity against human erythrocytes (17). Some hybrid molecules retain significant antifungal activity, are less hemolytic than Temporin-A, and inhibit blood coagulation (34). It is also noted that transgenic potatoes expressing $\mathrm{N}$-terminally modified Temporin-A (MsrA3) are resistant to late blight caused by Phytophthora infestans and pink rot caused by Phytophthora erythroseptica (22). Temporin-L readily penetrates into lipid monolayers; intercalation is enhanced in the presence of the common bacterial negatively charged phospholipid phosphatidylglycerol, whereas eukaryotic cholesterol counteracts penetration into lipid films to some extent (36); it has been shown that the simultaneous administration of Temporin- $\mathrm{L}$ and beta-lactams produce the highest antimicrobial activities and the strongest reduction in plasma endotoxin and TNF-alpha levels, resulting in the highest survival rates in two rat models of septic shock causes by Gram-negative bacteria (11). Temporin-Ma has been shown to induce mast cell degranulation and histamine release, and has cytotoxic activity toward solid tumor cell line HepG2 (14).

Ranatuerins are peptides with antimicrobial activity towards Staphylococcus aureus. Ranatuerin-1 shows the broadest spectrum of antimicrobial action with inhibitory activity against Staphylococcus aureus, Escherichia coli and Candida albicans. Ranatuerin-2P appears to inactivate frog virus 3 , a potentially pathogenic iridovirus infecting anurans, and channel catfish herpesvirus by direct action rather than inhibition of replication in infected cells (4). Ranatuerin-2TRa has been shown to be active against the pathogenic chytrid fungus Batrachochytrium dendrobatidis (27).

Nigrocins are cationic antimicrobial peptides which possess a broad spectrum of antimicrobial activity against various microorganisms with different specificity (24).

Japonicins are bacteristatic for Escherichia coli and the Gram-positive bacterium Staphylococcus aureus.

It has been shown that Ranacyclins and pLR have antimicrobial and antifungal activity but differ in their activity spectra (16).

Pipinin-1, yet the only known member of Pipinins family, is antimicrobial and has insulin releasing activity (20).

\section{Why Bulgarian scientists may be interested in FSAP?}

As a south-eastern part of European region, Bulgaria demonstrates a natural abundance of Amphibian organisms. There are 17 Amphibia species that inhabit the territory of Bulgaria (38). They include 12 frog species from 5 families (see Table 3 for details) and 5 salamander species from the family Salamandridae. The most recently discovered species is the Edible Frog which was first registered in 1966. Some of the most common species include the European Green Toad, Yellow-bellied toad and Marsh Frog.

Some of the Anura species listed above are not specific to Bulgarian habitat only and have been investigated by foreign authors. For some of the species it has been firmly shown to produce FSAP (Rana dalmatina, Rana $\mathrm{kl}$. 
Esculenta, Rana temporaria, Bufo bufo); other are known to produce biologically active neuropeptides (Bombina bombina); the rest are not examined yet (Bombina variegate, Bufo viridis, Hyla arborea, Pelobates fuscus, Pelobates syriacus, Rana graeca and Rana ridibunda). This opens up a space for Bulgarian scientists to prepare research projects mainly on two directions:

a. To confirm occurrence of known biologically active substances (and especially FSAP) in skin secretion of Anura species with Bulgarian origin;

b. To investigate the possibility for unexamined species to produce yet unknown biologically active substances (and especially FSAP).

It may sound reasonable to pay attention firstly at Rana $\mathrm{kl}$. Esculenta as a most reliable source of experimental material; moreover it should be mentioned here, that there are some recent traditions in Bulgarian Edible Frog breeding. Some preliminary clinical observations testify to the positive influence of $R$. Esculenta secretion on surface injuries elimination.

As a final goal of investigations should be set the answer of the question: "Is it possible to develop novel antibacterial drugs on the basis of naturally produced or synthetically made FSAP?".

\section{Which are preferable methods in FSAP investigation?}

The process of biochemical analysis regarding frog skin active peptides follows the routine way of polyaminocarboxylic acids examination. From physicochemical point of view it could be separated to steps as follows:

Biosampling. Crude secretion is usually obtained by mild electrical stimulation of the dorsal frog skin surface (20). Average biosample volume collected in this manner is about 5-10 mg. ( \pm )-Norepinephrine hydrochloride stimulation is also possible (1).

Preliminary purification. High-performance liquid chromatography (HPLC) techniques are preferred here. Widely used solvent system is tri?uoroacetic acid (TFA)/water/acetonitrile; absorbance monitoring at $214 \mathrm{~nm}$ (1). C-18 reversed-phase HPLC yields 50-100 fractions, which can be examined for bioactivity and processed further.

Deep purification. Chosen fractions often undergo rechromatographing (once or more) to enhance separation level. Final purification by C-4 HPLC leads to single homogenous peaks.

Sequence determination. Positive and negative ion electrospray mass spectrometry (ES-MS) could be used as a primary method to investigate the amino acid sequence (2). Edman automated degradation is helpful for additional clarification. Also, skin peptide precursor cDNA cloning techniques have been reported to be useful for FSAP family identification (37).

Biological activity study. After FSAP purification and isolation (or, in some cases, after their chemical synthesis) a series of tests should be done in order to examine peptide's antibiotic activities against specific micro-organisms and determine antimicrobial and/or antifungal activity. In accordance to opportunity of utilizing the FSAP' therapeutic potential, attention should be paid to their citotoxicity and hemolytic properties.

\section{CONCLUSION}

In present paper a naturally produced biologically active substances, as known as Frog Skin Active Peptides (FSAP) are discussed. The known general information regarding their origins as well as main biomedical properties are summarized. A brief classification has been presented. Preferable methods for FSAP analysis have been outlined. It has been demonstrated that FSAP are natural biomolecules of significant interest to the modern science, including chemistry, biochemistry, medicine and pharmacy.

Attention has been drawn to the opportunity of running systematical research on local Bulgarian Anura species as well as to actuality of studying the possibilities for drug development on the FSAP basis.

\section{REFERENCES}

1. Basir Y.J., Knoop F.C., Dulka J., Conlon J.M. Multiple antimicrobial peptides and peptides related to bradykinin and neuromedin $\mathrm{N}$ isolated from skin secretions of the pickerel frog, Rana palustris. Biochimica Biophysica Acta, 1543, 1 (2000), p. 95-105

2. Brinkworth C.S., Bowie J.H., Bilusich D., Tyler M.J. The rothein peptides from the skin secretion of Roth's tree frog Litoria rothii. Sequence determination using positive and negative ion electrospray mass spectrometry. Rapid Commun. Mass. Spectrom., 19, 18 (2005), p. 2716-2724.

3. Chen Q., Wade D., Kurosaka K., Zhao Y.W., Oppenheim J.J., De Yang. Temporin A and related frog antimicrobial peptides use formyl peptide receptor-like 1 as a receptor to chemoattract phagocytes. Journal of Immunology, 173, 4 (2004), p. 2652-2659

4. Chinchar V.G., Wang J., Murti G., Carey C., Rollins-Smith L. Inactivation of frog virus 3 and channel catfish virus by esculentin-2P and ranatuerin-2P, two antimicrobial peptides isolated from frog skin. Virology, 288, 2 (2001), p. 351-357

5. Clark D.P., Durell S., Maloy W.L., Zasloff M. Ranalexin. A novel antimicrobial peptide from bullfrog (Rana catesbeiana) skin, structurally related to the bacterial antibiotic, polymyxin. Journal of Biological Chemistry, 269, 14 (1994), p. 10849-10855

6. Conlon J. Reflections on a systematic nomenclature for antimicrobial peptides from the skins of frogs of the family Ranidae. Peptides, 29, 10 (2008), p. 1815-1819

7. Ghiselli R., Giacometti A., Cirioni O., Orlando F., Mocchegiani F., Mataloni P., Scalise T.G., Saba V. Therapeutic efficacy of the polymyxin-like peptide Ranalexin in an experimental model of endotoxemia. Journal of Surgical Research, 100, 2 (2001), p. 183-188 
Frog skin active peptides (FSAP) as a highy effective antimicrobial agents

8. Giacometti A., Cirioni O., Greganti G., Quarta M., Scalise G. In vitro activities of membrane-active peptides against gram-positive and gram-negative aerobic bacteria. Antimicrobial Agents and Chemotherapy, 42, 12 (1998), p. 3320-3324

9. Giacometti A., Cirioni O., Barchiesi F., Caselli F., Scalise G. In-vitro activity of polycationic peptides against Cryptosporidium parvum, Pneumocystis carinii and yeast clinical isolates. Journal of Antimicrobial Chemotherapy, 44, 3 (1999), p. 403-406

10. Giacometti A., Cirionia O., Ghisellib R., Goffib L., Mocchegianib F., Rivaa A., Scalisea G., Sabab V. Efficacy of polycationic peptides in preventing vascular graft infection due to Staphylococcus epidermidis. Journal of Antimicrobial Chemotherapy, 46, 5 (2000), p. 751-756

11. Giacometti A., Cirioni O., Ghiselli R., Mocchegiani F., Orlando F., Silvestri C., Bozzi A., Di Giulio A., Luzi C., Mangoni M.L., Barra D., Saba V., Scalise G., Rinaldi A. Interaction of antimicrobial peptide Temporin $\mathrm{L}$ with lipopolysaccharide in vitro and in experimental rat models of septic shock caused by gram-negative bacteria. Antimicrobial Agents and Chemotherapy, 50, 7 (2006), p. 2478-2486

12. Goraya J., Knoop F.C., Conlon J.M. Rnatuerins: antimicrobial peptides isolated from the skin of the American bullfrog, Rana catesbeiana. Biochemical Biophysical Research Communications, 250, 3 (1998), p. 589-592

13. Isaacson T., Soto A., Iwamuro S., Knoop F.C., Conlon J.M. Antimicrobial peptides with atypical structural features from the skin of the Japanese brown frog Rana japonica. Peptides, 23, 3 (2002), p. 419-425

14. Lu Y., Jianxu L., Haining Y., Xueqing X., Jianguo L., Yongqiang T., Dongying M., Guoqing L., Guoqiang H., Ren L. Two families of antimicrobial peptides with multiple functions from skin of rufous-spotted torrent frog, Amolops loloensis. Peptides, 27, 12, (2006), p. 3085-3091

15. Mangoni M.L., Rinaldi A., Di Giulio A., Mignogna G., Bozzi A., Barra D., Simmaco M. Structure-function relationships of Temporins, small antimicrobial peptides from amphibian skin. European Journal of Biochemistry, 267, 5 (2000), p. 1447-1454

16. Mangoni M.L., Papo N., Mignogna G., Andreu D., Shai Y., Barra D., Simmaco M. Ranacyclins, a new family of short cyclic antimicrobial peptides: biological function, mode of action, and parameters involved in target specificity. Biochemistry, 42, 47 (2003), p. 14023-14035

17. Mangoni M.L., Saugar J.M., Dellisanti M., Barra D., Simmaco M., Rivas L. Temporins, small antimicrobial peptides with leishmanicidal activity. Journal of Biological Chemistry, 280, 2 (2005), p. $984-990$

18. Mantyla T., Sirola H., Kansanen E., Korjamo T., Lankinen H., Lappalainen K., Valimaa A.L., Harvima I., Narvanen A. Effect of temporin-A modifications on its cytotoxicity and antimicrobial activity. APMIS, 113, 7-8 (2005), p. 497-505

19. Marenah L., Flatt P.R., Orr D.F., McClean S., Shaw C., Abdel-Wahab Y.H. Brevinin-1 and multiple insulin-releasing peptides in the skin of the frog Rana palustris. Journal of Endocrinology, 181, 2 (2004), p. 347-354

20. Marenah L., Flatt P.R., Orr D.F., Shaw C., Abdel-Wahab Y.H.A. Characterization of naturally occurring peptides in the skin secretion of Rana pipiens frog reveal pipinin-1 as the novel insulin-releasing agent. Journal of Peptide Research, 66, 4 (2005), p. 204-210

21. Morikawa N., Hagiwara K., Nakajima T. Brevinin-1 and -2, unique antimicrobial peptides from the skin of the frog, Rana brevipoda porsa. Biochemical Biophysical Research Communications, 189, 1 (1992), p. 184-190

22. Osusky M., Osuska L., Hancock R.E., Kay W.W., Misra S. Transgenic potatoes expressing a novel cationic peptide are resistant to late blight and pink rot. Transgenic Research, 13, 2 (2004), p. 181-190

23. Pal T., Abraham B., Sonnevend A., Jumaa P., Conlon J. Brevinin-1BYa: a naturally occurring peptide from frog skin with broad-spectrum antibacterial and antifungal properties. International Journal of Antimicrobial Agents, 27, 6 (2006), p. 525-529

24. Park S., Park S.-H., Ahn H.-C., Kim S., Kim S.S., Lee B.J., Lee B.-J. Structural study of novel antimicrobial peptides, nigrocins, isolated from Rana nigromaculata. FEBS Letters, 507, 1 (2001), p. 95-100

25. Ponti D., Mangoni M.L, Mignogna G., Simmaco M., Barra D. An amphibian antimicrobial peptide variant expressed in Nicotiana tabacum confers resistance to phytopathogens. Biochemical Journal, 370, 1 (2003), p. 121-127

26. Roice M., Suma G., Kumar K.S., Pillai V.N.R. Synthesis of esculentin-1 antibacterial peptide fragments on 1,4-butanediol dimethacrylate cross-linked polystyrene support. Journal of Protein Chemistry, 20, 1 (2001), p. 25-32

27. Rollins-Smith L.A., Reinert L.K., Miera V., Conlon J.M. Antimicrobial peptide defenses of the Tarahumara frog, Rana tarahumarae. Biochemical Biophysical Research Communications, 297, 2 (2002), p. 361-367

28. Rollins-Smith L.A., Carey C., Conlon J.M., Reinert L.K., Doersam J.K., Bergman T., Silberring J., Lankinen H., Wade D. Activities of Temporin family peptides against the chytrid fungus (Batrachochytrium dendrobatidis) associated with global amphibian declines. Antimicrobial Agents and Chemotherapy, 47, 3 (2003), p. 1157-1160

29. Simmaco M., Mignogna G., Barra D., Bossa F. Novel antimicrobial peptides from skin secretion of the European frog Rana esculenta. FEBS Letters, 324, 2 (1993), p. 159-161

30. Simmaco M., Mignogna G., Barra D., Bossa F. Antimicrobial peptides from skin secretions of Rana esculenta. Molecular cloning of cDNAs encoding esculentin and brevinins and isolation of new ac- 
tive peptides. Journal of Biological Chemistry, 269, 16 (1994), p. 11956-11961

31. Simmaco M., Mignogna G., Canofeni S., Miele R., Mangoni M.L., Barra D. Temporins, antimicrobial peptides from the European red frog Rana temporaria. Biochemical Biophysical Research Communications, 212 (1995), p. 249-254

32. Suzuki S., Ohe Y., Okubo T., Kakegawa T., Tatemoto $\mathrm{K}$. Isolation and characterization of novel antimicrobial peptides, rugosins A, B and C, from the skin of the frog, Rana rugosa. Biochemical Biophysical Research Communications, 212, 1 (1995), p. 249-254

33. Wade D., Silberring J., Soliymani R., Heikkinen S., Kilpelдinen I., Lankinen H., Kuusela P. Antibacterial activities of Temporin A analogs. FEBS Letters, 479, 1-2 (2000), p. 6-9

34. Wade D., Silveira A., Rollins-Smith L., Bergman T., Silberring J., Lankinen H. Hematological and antifungal properties of Temporin A and a cecropin A-Temporin A hybrid. Acta Biochimica Polonica, 48, 4 (2001), p. 1185-1189

35. Yasin B., Pang M., Turner J.S., Cho Y., Dinh N.-N., Waring A.J., Lehrer R.I., Wagar E.A.
Evaluation of the inactivation of infectious Herpes simplex virus by host-defense peptides. European Journal of Clinical Microbiology and Infectious Diseases, 19, 3 (2000), p. 187-194

36. Zhao H., Rinaldi A., Di Giulio A., Simmaco M., Kinnunen P. Interactions of the antimicrobial peptides Temporins with model biomembranes. Comparison of Temporins B and L. Biochemistry, 41, 13 (2002), p. 4425-4436

37. Zhou M., Chen T., Walker B., Shaw C. Pelophylaxins: Novel antimicrobial peptide homologs from the skin secretion of the Fukien gold-striped pond frog, Pelophylax plancyi fukienensis Identification by "shotgun" cDNA cloning and sequence analysis. Peptides, 27, 1 (2006), p. 36-41

38. Бешков В., Нанев К. Земноводни и влечуги в България. Изд. „Пенсофт” (2002)

39. C O P E: Cytokines \& Cells Online Pathfinder Encyclopaedia, Version 19.4 (April 2007) Online at: http://www.copewithcytokines.de/cope.cgi

40. Protein knowledgebase, UniProt Consortium, (C) 2002-2008 Online at: http://www.uniprot.org/uniprot/ 